\title{
Salix matsudana Koidz Tolerance Mechanisms to Cadmium: Uptake and Accumulation, Subcellular Distribution, and Chemical Forms
}

\author{
Hangfeng Wu, Jiayue Wang, Binbin Li, Yangjie Ou, Junran Wang, \\ Qiuyue Shi, Wusheng Jiang, Donghua Liu, Jinhua Zou* \\ Tianjin Key Laboratory of Animal and Plant Resistance, College of Life Sciences, Tianjin Normal University, \\ Tianjin 300387, People's Republic of China
}

Received: 5 March 2016

Accepted: 18 April 2016

\begin{abstract}
Salix matsudana roots exposed to 10,50 , and $100 \mu \mathrm{M}$ Cd solutions for $24 \mathrm{~h}$ were carried out in order to understand the mechanisms involved in $\mathrm{Cd}$ tolerance and detoxification. 50 and $100 \mu \mathrm{M} \mathrm{Cd}$ inhibited root length significantly $(\mathrm{P}<0.05)$. Cd levels in roots increased significantly with increasing $\mathrm{Cd}$ concentrations, and the contents of $\mathrm{Fe}, \mathrm{Mn}, \mathrm{Zn}$, and Ca decreased significantly. A Cd-specific Leadmium Green AM dye probe showed that the meristem zone was the absorption and accumulation site of $\mathrm{Cd}$ in the roots. Subcellular fractionation of Cd-containing tissues indicated that about $53 \%$ of the $\mathrm{Cd}$ was accumulated in the cell wall of $S$. matsudana roots at $10 \mu \mathrm{M} \mathrm{Cd}$ and $65 \%$ of the $\mathrm{Cd}$ at $100 \mu \mathrm{M} \mathrm{Cd}$, indicating that $\mathrm{Cd}$ binding and/or precipitation in the cell wall in roots may serve as the first barrier to reduce the cytosolic-free Cd ions. The proportion of $\mathrm{CdE}$ and $\mathrm{Cdw}$ in roots is low when compared with the other $\mathrm{Cd}$ chemical forms. $\mathrm{CdHCl}, \mathrm{Cdr}$, and CdHAc represent 46\% (10 $\mu \mathrm{M} \mathrm{Cd}), 49 \%(50 \mu \mathrm{M} \mathrm{Cd})$, and 59\% (100 $\mu \mathrm{M} \mathrm{Cd})$ of total $\mathrm{Cd}$, and $\mathrm{CdNaCl}$ represents $42 \%(10 \mu \mathrm{M} \mathrm{Cd}), 44 \%(50 \mu \mathrm{M} \mathrm{Cd})$, and $32 \%(100 \mu \mathrm{M} \mathrm{Cd})$.
\end{abstract}

Keywords: cadmium (Cd), chemical forms, Salix matsudana Koidz, subcellular distribution, uptake and accumulation

\section{Introduction}

Cadmium $(\mathrm{Cd})$ is inorganic minerals in the earth's crust [1]. Cd contamination is considered a major environmental problem due to its great toxicity to all organisms and its high mobility and risk to the food chain $[2,3]$. Cd is a non-essential element, and excessive $\mathrm{Cd}$ can target and damage many cellular activities and

*e-mail: zjhmon@163.com processes such as photosynthesis, carbohydrate and nitrate metabolism, water balance, and DNA and lipid matrix, resulting in growth inhibition, morphological alterations, and plant senescence or even death [4]. Cd interferes with the uptake, transport, and use of different macro- and micronutrients [5]. Microelements (zinc ( $\mathrm{Zn})$, iron (Fe), manganese (Mn), and selenium (Se)) interfering with $\mathrm{Cd}$ uptake may decrease $\mathrm{Cd}$ concentrations in plants [1]

Recent research has focused on the accumulation and tolerance mechanisms of heavy metals in plants. Subcellular partitioning of metals within living cells has 
attracted great interest because of their importance in eco-toxicological and trophic transfer studies [6]. Nonessential metals accumulated in the cell wall and vacuole is another detoxification process that prevents them from entering more sensitive cell metabolic sites [7]. The vacuole can be considered the most important component in the soluble fraction of a cell [8]. In order to avoid $\mathrm{Cd}$ toxicity, plants have developed intra and extra cellular mechanisms for metal detoxification, such as binding and precipitation in the cell wall and/or compartmentalization in vacuoles [9-10].

Regionalization of cell wall deposition and vacuolar compartmentation play a major role in heavy metal detoxification, tolerance, and hyperaccumulation in plants [11]. Cell walls and vacuoles in plant roots are considered to have great potential for $\mathrm{Cd}$ accumulation [6]. There is some evidence that subcellular distribution and chemical forms of heavy metals may be associated with metal tolerance and detoxification in plants [12]. Cd phytotoxicity was related to the $\mathrm{Cd}$ chemical forms in plant tissues and their mobility in the plants [13]. Ernst et al. [14] and Rauser [15] indicated that $\mathrm{Cd}$ bound by pectate and chelated by peptides, polypeptides, or proteins is a defense mechanism to reduce the $\mathrm{Cd}$ biological activity in plants. Evidence on $\mathrm{Cd}$ integration in pectates and proteins and $\mathrm{Cd}$ ligands in vacuoles was reported $[8,11]$. However, the stored forms of $\mathrm{Cd}$ in different plant tissues are concerned with the capacity of plant $\mathrm{Cd}$ tolerance and accumulation $[13,16$, 17]. Larger proportions of $\mathrm{NaCl}$-extractable $\mathrm{Cd}$ in plants can be thought to play an important role in the alleviation of Cd toxicity. The complexation of metals with organic ligands can result in decreased free ion activity and thus reduce their toxicity [18].

Willows (Salix spp.) is known to have several characteristics that make them ideal plant species for phytoremediation application, including easy propagation and cultivation, large biomass, fast growing, deep root system, high transpiration rate, tolerance to hypoxic conditions, and high metal accumulation capability [19]. Salix matsudana Koidz is one of the most widely distributed and commonly cultivated willow species in China [20]. It also has a deep root system compared to grasses, which can act as a biological filter. These traits make it a potential ideal candidate for phytoremediation of Cd-contaminated waters and soils [21, 22].

Root is the plant organ for the uptake of various nutrients as well as metals, including Cd. Resistance to Cd stress is associated with two aspects: avoidance and tolerance. Avoidance is a basic mechanism to mitigate $\mathrm{Cd}$ toxicity, which involves decreasing the amount of $\mathrm{Cd}$ entering the cell by extracellular precipitation, biosorption to cell walls, reduced uptake, or increased efflux. Tolerance means plants survive in the presence of high internal metal concentration $[1,23]$. Excessive $\mathrm{Cd}$ has often caused poisoning and environmental contamination. Therefore, the evaluation of action mechanisms of $\mathrm{Cd}$ toxic to $S$. matsudana roots and their consequences on absorption site, uptake, accumulation, and its effects on elements, subcellular distribution, and chemical form, as performed in the present investigation, is important. Therefore, the aims of this study were to investigate the characteristics of $\mathrm{Cd}$ uptake and accumulation, localization, and subcellular distribution, and chemical forms in S. matsudana roots and their implication in $\mathrm{Cd}$ tolerance.

\section{Materials and Methods}

\section{Plant Material and Growth Conditions}

Healthy and equally sized cuttings (25 cm long) from 1 -year-old shoots of $S$. matsudana were collected and fully rinsed with distilled water before starting the experiments. After dipping in distilled water at room temperature, 10-day-old healthy seedlings were transferred to a halfstrength Hoagland nutrient solution and grown for a week. Then Cd was added to the corresponding containers to form four treatments: basal nutrient solution (control, without Cd) and 10, 50, and $100 \mu \mathrm{M} \mathrm{Cd}$. for $24 \mathrm{~h}$. Cadmium was provided as cadmium chloride $\left(\mathrm{CdCl}_{2}\right)$.

The nutrient solution consisted of $5 \mathrm{mM} \mathrm{Ca}\left(\mathrm{NO}_{3}\right)_{2}$, $5 \mathrm{mM} \mathrm{KNO}_{3}, 1 \mathrm{mM} \mathrm{KH_{2 } \mathrm { PO } _ { 4 } , 1 \mathrm { mM } \mathrm { MgSO }}, 50 \mu \mathrm{M}$

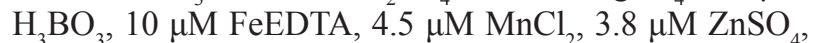
$0.3 \mu \mathrm{M} \mathrm{CuSO}_{4}$, and $0.1 \mu \mathrm{M}\left(\mathrm{NH}_{4}\right) 6 \mathrm{Mo}_{7} \mathrm{O}_{24}$, adjusted to $\mathrm{pH}$ 5.5. Control seedlings were grown in the nutrient solution alone. The solutions were continuously aerated with an aquarium air pump every day.

\section{Determination of $\mathrm{Cd}$ and Other Minerals}

Seedlings exposed to 10,50 , and $100 \mu \mathrm{M}$ Cd solutions for $24 \mathrm{~h}$ and control were harvested respectively based on uniformity of size and colour (removing the greatest and the smallest seedlings and then selected randomly). The seedlings were washed with $20 \mathrm{mM}$ EDTA, thoroughly with running tap water, and then with deionized water, and roots were separated manually and dried in an oven at $80^{\circ} \mathrm{C}$ for one week for metal analysis. Accumulations of $\mathrm{Cd}, \mathrm{Mn}, \mathrm{Zn}, \mathrm{Ca}$, and $\mathrm{Fe}$ were analyzed using inductively coupled plasma atomic emission spectrometry (ICP-AES, LEEMAN LABS Inc., USA) [24].

\section{Tissue Fractionation}

Cells were separated into three fractions (cell wall, organelle-containing, and soluble fractions) according to the improved method reported by $[8,25]$. S. matsudana roots exposed to 10,50 , and $100 \mu \mathrm{M} \mathrm{Cd}$ solutions for $24 \mathrm{~h}$ were separated, then rinsed cleanly with $20 \mathrm{mM}$ EDTA and deionized water. Each sample was homogenized in $20 \mathrm{~mL}$ cooled extraction buffer (50 mM Tris- $\mathrm{HCl}, 250 \mathrm{mM}$ sucrose and $1.0 \mathrm{mM}$ $\mathrm{C}_{4} \mathrm{H}_{10} \mathrm{O}_{2} \mathrm{~S}_{2}, \mathrm{pH}$ 7.5) with a chilled mortar and a pestle. The homogenate was centrifuged at 4,000 rpm for $15 \mathrm{~min}$; centrifugation was repeated twice and the precipitate was designated as "cell wall-containing fraction" consisting mainly of cell walls and cell wall debris. The supernatant 
solution was further centrifuged at 12,000 rpm for $45 \mathrm{~min}$. The resultant deposition and supernatant solution were referred to as the "organelle-containing fraction" and the "soluble fraction," respectively. All steps were performed at $4^{\circ} \mathrm{C}$. The different fractions were wet-digested with $\mathrm{HNO}_{3}: \mathrm{HClO}_{4}(4: 1, \mathrm{v} / \mathrm{v})$, and the content of $\mathrm{Cd}$ in the solutions was measured using ICP (ICP-AES, LEEMAN LABS Inc., USA).

\section{Chemical Forms Extraction}

The Cd associated with different chemical forms was successively extracted by designated solutions in the following order $[8,26]$ :

1. $80 \%$ ethanol, extracting inorganic $\mathrm{Cd}$ giving priority to nitrate, chloride, and aminophenol cadmium $(\mathrm{CdE})$.

2. Deionized water, extracting water-soluble $\mathrm{Cd}$ with organic acids and $\mathrm{Cd}\left(\mathrm{H}_{2} \mathrm{PO}_{4}\right)_{2}(\mathrm{Cdw})$.

3. $1 \mathrm{M} \mathrm{NaCl}$, extracting pectate- and protein-integrated $\mathrm{Cd}(\mathrm{CdNaCl})$.

4. $2 \% \mathrm{HAc}$, extracting insoluble $\mathrm{CdHPO}_{4}, \mathrm{Cd}_{3}\left(\mathrm{PO}_{4}\right)_{2}$, and other Cd-phosphate complexes (CdHAc).

5. $0.6 \mathrm{M} \mathrm{HCl}$, extracting oxalic acid bound $\mathrm{Cd}(\mathrm{CdHCl})$.

6. Cadmium in residues (Cdr).

The Roots of $S$. matsudana Seedlings exposed to 10,50 , and $100 \mu \mathrm{M} \mathrm{Cd}$ solutions for $24 \mathrm{~h}$ were separated, then rinsed cleanly with $20 \mathrm{mM}$ EDTA and deionized water. Each sample was extracted with $20 \mathrm{~mL}$ of buffer solution that contained designated solutions (as shown above). Firstly, the homogenate was shaken for $22 \mathrm{~h}$ at $25^{\circ} \mathrm{C}$ and centrifuged at 5,000 rpm for $10 \mathrm{~min}$. Then the supernatant was collected. After that, $10 \mathrm{~mL}$ of buffer solution was added to the centrifuge tube and the tube was shaken for $2 \mathrm{~h}$ at $25^{\circ} \mathrm{C}$. At last, the homogenate was centrifuged under the same conditions for another $10 \mathrm{~min}$ and the supernatant was collected. This procedure was repeated twice. The $\mathrm{Cd}$ content of the plant material remaining after all of the extractions and all of extracting solution had been conducted was determined by wet-digesting it with $\mathrm{HNO}_{3}: \mathrm{HClO}_{4}(4: 1, \mathrm{v} / \mathrm{v})$. The content of $\mathrm{Cd}$ in different chemical forms was measured by ICP (ICP-AES, LEEMAN LABS Inc., USA).

\section{Fluorescence Labeling of $\mathrm{Cd}$}

The Cd Probe Leadmium Green AM dye (Molecular Probes, Invitrogen, Calsbad, CA, USA) was used to investigate the distribution of $\mathrm{Cd}$ in roots of plants exposed to 10,50 , and $100 \mu \mathrm{M} \mathrm{Cd}$ solutions for $24 \mathrm{~h}$. Fresh and intact root tips of $S$. matsudana were incubated for $10 \mathrm{~min}$ in excess of $20 \mathrm{mM}$ disodium ethylenediamine tetra-acetic acid ( $\mathrm{Na}_{2}$-EDTA) at room temperature, and then thoroughly washed with deionized water. A Cdspecific probe was made by adding $50 \mu \mathrm{L}$ of dimethyl sulfoxide to one vial of the dye. This stock solution was then diluted 1:10 with $0.85 \% \mathrm{NaCl}$ [27]. The roots were immersed in diluted stock solution at $40^{\circ} \mathrm{C}$ for $90 \mathrm{~min}$ in the dark. The sections were examined with a laser confocal scanning microscope (ECLIPSE 90i, Nikon, Japan) with excitation and emission wavelengths at 488 and $515 \mathrm{~nm}$, respectively. The fluorescence density was measured using the analyze and measure function of the Image J software (NIH, Bethesda, MD, USA).

\section{Statistical Analysis}

Data from this investigation were analyzed with Sigma Plot 13.0 using means \pm standard error (SE). For equality of averages the t-test was applied. Results were considered statistically significant at $P<0.05$.

\section{Results}

\section{Effects of Cd on Root Growth}

The effects of Cd on the root growth of S. matsudana varied with the different treatment concentrations used (Fig. 1). Compared with control, $\mathrm{Cd}$ had no toxic effect on root growth at $10 \mu \mathrm{M} \mathrm{Cd}$ during $24 \mathrm{~h}$ treatment. However, in concentrations of 50 and $100 \mu \mathrm{M} \mathrm{Cd}$ an obvious toxic effect appeared and $\mathrm{Cd}$ inhibited root growth significantly $(P<0.05)$

\section{Cd Accumulation and its Effects on Other Minerals}

Statistical analysis showed the presence of significant correlations between the concentrations of $\mathrm{Cd}$ and microelements (Fe, Mn, $\mathrm{Zn}$, and $\mathrm{Ca}$ ). The accumulation of $\mathrm{Cd}$ in $S$. matsudana roots varied with the different treatment concentrations. The level of $\mathrm{Cd}$ in roots increased significantly $(P<0.05)$ with increasing Cd concentrations when compared with control (Table 1). Cd had obvious inhibitory effects on uptake and accumulation of Fe, Mn, $\mathrm{Zn}$, and $\mathrm{Ca}$ in roots. The contents of $\mathrm{Fe}, \mathrm{Mn}, \mathrm{Zn}$, and

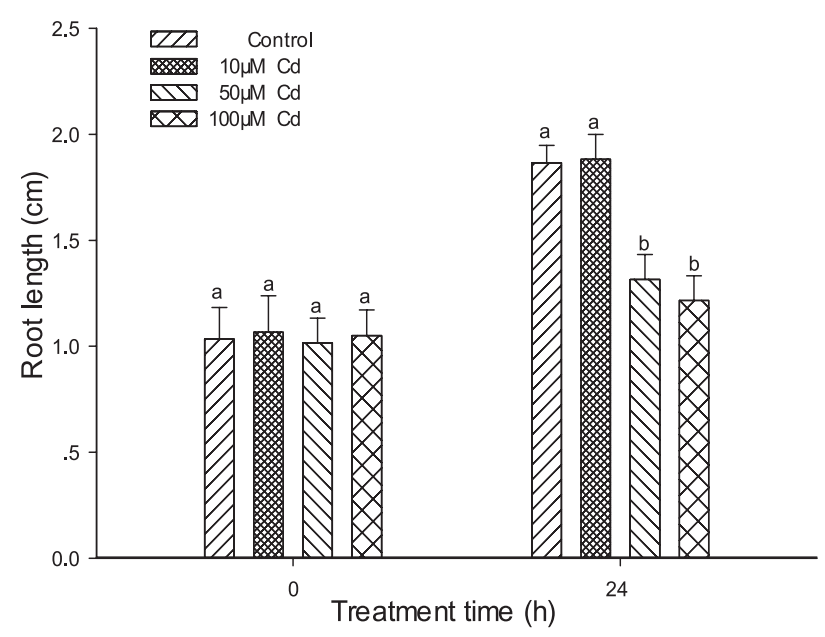

Fig. 1. Effects of $\mathrm{Cd}$ on root length of S. matsudana exposed to 10,50 , and $100 \mu \mathrm{M}$ Cd for $24 \mathrm{~h}$. Vertical bars denote SE. Values with different letters differ significantly from each other $(\mathrm{n}=10$, $P<0.05)$. 
Table 1. Cd, Mn, Fe, Zn, and Ca accumulation by S. matsudana roots exposed to different concentrations of Cd for $24 \mathrm{~h}$.

\begin{tabular}{|c|c|c|c|c|}
\hline \multirow{2}{*}{ Element } & \multicolumn{4}{|c|}{$\mu \mathrm{g} \mathrm{g}^{-1}$ dry weight } \\
\cline { 2 - 5 } & \multicolumn{4}{|c|}{ Treatment $\mu \mathrm{M}$} \\
\cline { 2 - 5 } & Control & 10 & 50 & 100 \\
\hline $\mathrm{Cd}$ & $0.00 \pm 0.00 \mathrm{a}$ & $274.93 \pm 0.90 \mathrm{~b}$ & $866.38 \pm 3.48 \mathrm{c}$ & $1477.338 \pm 2.91 \mathrm{~d}$ \\
\hline $\mathrm{Fe}$ & $723.55 \pm 10.64 \mathrm{a}$ & $474.83 \pm 3.27 \mathrm{~b}$ & $449.37 \pm 2.58 \mathrm{c}$ & $359.04 \pm 3.97 \mathrm{~d}$ \\
\hline $\mathrm{Mn}$ & $547.56 \pm 0.96 \mathrm{a}$ & $421.96 \pm 2.28 \mathrm{~b}$ & $389.37 \pm 6.47 \mathrm{c}$ & $120.38 \pm 1.04 \mathrm{~d}$ \\
\hline $\mathrm{Zn}$ & $590.85 \pm 2.28 \mathrm{a}$ & $397.0 \pm 4.57 \mathrm{~b}$ & $365.77 \pm 11.52 \mathrm{c}$ & $249.17 \pm 6.83 \mathrm{~d}$ \\
\hline $\mathrm{Ca}$ & $5614.95 \pm 24.49 \mathrm{a}$ & $4777.89 \pm 44.18 \mathrm{~b}$ & $4457.88 \pm 15.41 \mathrm{c}$ & $3109.67 \pm 10.20 \mathrm{~d}$ \\
\hline
\end{tabular}

Values followed by different letters are significantly different $(P<0.05)$. Vertical bars denote SE $(n=4)$.

$\mathrm{Ca}$ in roots decreased significantly with increasing $\mathrm{Cd}$ concentrations $(P<0.05)$. In concentrations of $100 \mu \mathrm{M} \mathrm{Cd}$ group, $\mathrm{Cd}$ stress caused a $50.4 \%$ decrease of Fe content, $78.0 \%$ of $\mathrm{Mn}, 57.8 \%$ of $\mathrm{Zn}$, and $44.6 \% \mathrm{Ca}$ in roots when compared with the control group.

\section{Cd Distribution in Different Zones}

The distribution of $\mathrm{Cd}$ in the root tips of $S$. matsudana exposed to 10,50 , and $100 \mu \mathrm{MCd}$ for $24 \mathrm{~h}$ was investigated using the Cd-specific Leadmium Green AM dye probe (Invitrogen, Carlsbad, CA, USA; Fig. 2). The fluorescent dye showed a bright and clear green fluorescence in the root tip cells of Cd-treated roots, whereas there was no green fluorescence signal in control root tips (Figs 2A1-A2). The fluorescent dye loaded into the roots showed different fluorescence intensity in the root tip cells exposed to different concentrations of $\mathrm{Cd}$ for $24 \mathrm{~h}$. A weak green fluorescence labeling of $\mathrm{Cd}$ was distributed

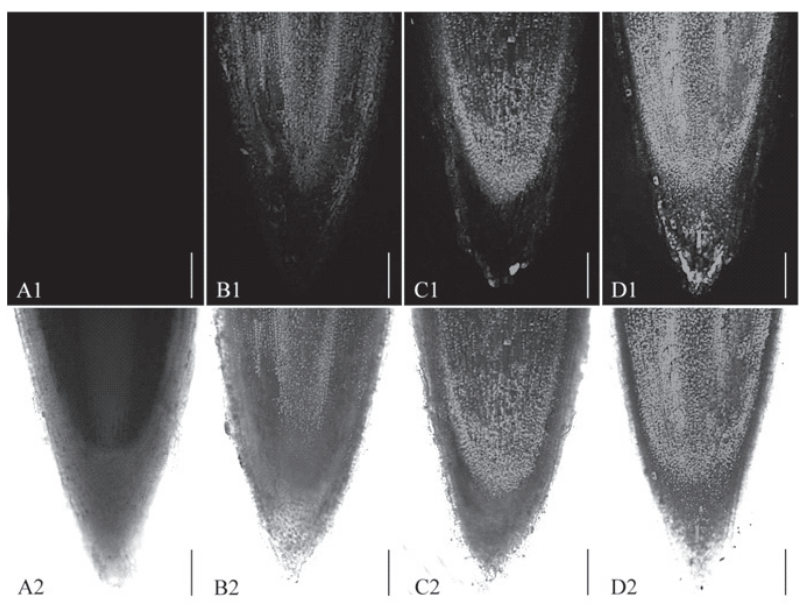

Fig. 2. Micrographs of roots from S. matsudana exposed to $\mathrm{Cd}$ using Leadmium Green AM dye at longitudinal section (A1D1). Showing Cd detection images of the roots exposed to 0 (A), 10 (B), 50 (C), and 100 (D) $\mu \mathrm{M}$ Cd for $24 \mathrm{~h}$, respectively (A2D2). Showing fluorescence labeling merged with a bright field. All images were taken with decuple magnification, Scale bars $=200 \mu \mathrm{m}$, and green fluorescence represents the binding of the dye to $\mathrm{Cd}$. in the meristematic cells exposed to $10 \mu \mathrm{M}$ (Figs 2 $\mathrm{B} 1-\mathrm{B} 2)$. At $50 \mu \mathrm{M} \mathrm{Cd}$, the labeling of the meristematic cells increased (Figs 2C1-C2). The strongest fluorescence in meristematic cells was observed at $100 \mu \mathrm{M} \mathrm{Cd}$ of incubation (Figs 2D1-D2).

These results indicated that $\mathrm{Cd}$ ions were localized in meristematic cells and increased with increasing $\mathrm{Cd}$ concentrations. The fluorescence density analysis of $\mathrm{Cd}$ was carried out by Image $\mathrm{J}$ software, confirming the observations mentioned above (Fig. 3). The data showed that the meristem zone was the absorption and accumulation site of $\mathrm{Cd}$ in the roots of $S$. matsudana under Cd stress.

\section{Subcellular Distribution of $C d$}

The subcellular distribution of $\mathrm{Cd}$ in roots was expressed as $\mathrm{Cd}$ concentration in the different fractions. In the present investigation, the subcellular distribution of $\mathrm{Cd}$ in S. matsudana roots exposed to 10, 50, and $100 \mu \mathrm{M}$ Cd for $24 \mathrm{~h}$ was in the following order: cell wall $>$ soluble fraction $>$ cell organelle (Table 2). The levels

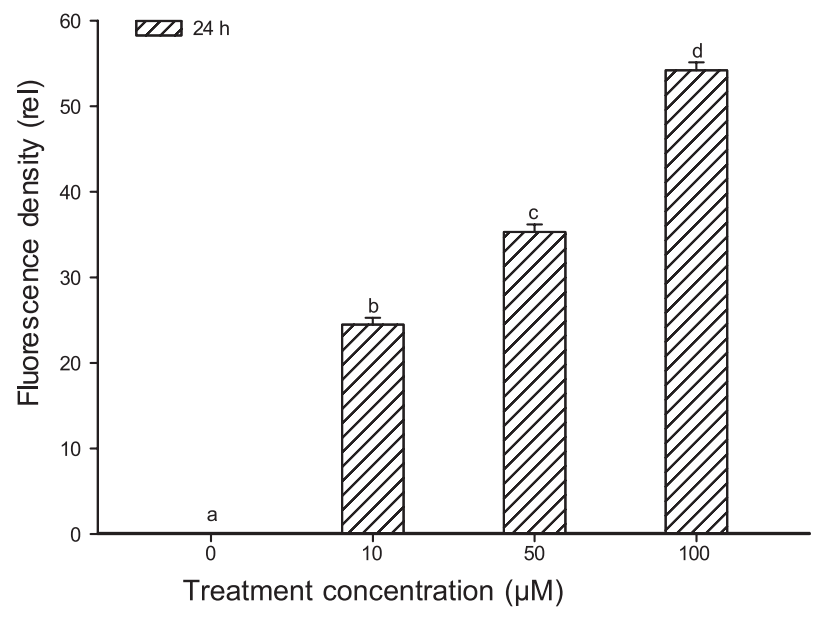

Fig. 3. Leadamium Green AM dye fluorescence density from the longitudinal section in S. matsudana on roots exposed to 10 , 50 , and $100 \mu \mathrm{M} \mathrm{Cd}$ for $24 \mathrm{~h}$. Values with different letters differ significantly from each other $(\mathrm{n}=5, P<0.05)$. Data are means \pm SE. 
Table 2. Subcellular distribution of Cd content in different organs in roots of $S$ matsudana exposed to 10, 50, and $100 \mu \mathrm{M} \mathrm{Cd}$ for $24 \mathrm{~h}$.

\begin{tabular}{|c|c|c|c|}
\hline \multirow{2}{*}{ Treatment $(\mu \mathrm{M})$} & \multicolumn{3}{|c|}{ Cd in subcellular distribution $(\mu \mathrm{g} / \mathrm{g} \mathrm{FW})$} \\
\cline { 2 - 4 } & Cell wall & Cell organelle & Soluble fraction \\
\hline 10 & $142.05 \pm 1.99 \mathrm{a}$ & $33.54 \pm 1.74 \mathrm{a}$ & $90.36 \pm 0.37 \mathrm{a}$ \\
\hline 50 & $507.64 \pm 2.59 \mathrm{~b}$ & $95.844 \pm 0.71 \mathrm{~b}$ & $240.46 \pm 0.50 \mathrm{~b}$ \\
\hline 100 & $947.64 \pm 7.06 \mathrm{c}$ & $129.19 \pm 3.71 \mathrm{c}$ & $381.37 \pm 1.02 \mathrm{c}$ \\
\hline
\end{tabular}

Values followed by different letters differ significantly from each other $(P<0.05, \mathrm{t}$-test $)$. Means $\pm \mathrm{SE}, \mathrm{n}=4$.

of Cd increased significantly $(P<0.05)$ with increasing $\mathrm{Cd}$ concentrations. Data also revealed that the contents of $\mathrm{Cd}$ in the cell wall, soluble fractions, and cell organelle of $S$. matsudana roots were $142.0,90.4$, and $33.5 \mu \mathrm{g} / \mathrm{g}$, respectively, after $24 \mathrm{~h}$ treatment with $10 \mu \mathrm{M} \mathrm{Cd}$. However, the accumulation of $\mathrm{Cd}$ increased by 5.7-, 3.2-, and 2.9-fold in the roots exposed to $100 \mu \mathrm{M} \mathrm{Cd}$ for $24 \mathrm{~h}$ in comparison with the $10 \mu \mathrm{M}$ Cd treatment (Table 2).

During the whole experiment the maximum proportion of $\mathrm{Cd}$ in roots was related to the cell wall, followed by the soluble cell organelle fraction. With the increase of $\mathrm{Cd}$ concentration, the proportion of $\mathrm{Cd}$ in cell wall increased, while the proportion of $\mathrm{Cd}$ in soluble and cell organelle fraction decreased (Fig. 4). For instance, with exposure to $100 \mu \mathrm{M} \mathrm{Cd}$, on average $65.0,26.0$, and $9.0 \% \mathrm{Cd}$ was

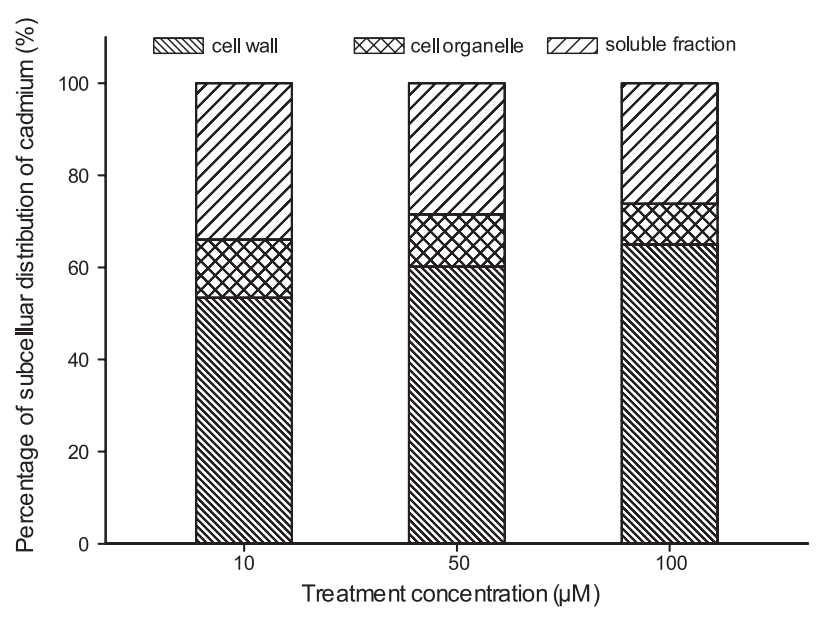

Fig. 4. Proportional changes of $\mathrm{Cd}$ ion contents in cell wall, soluble, and cell organelle fraction in roots of $S$. matsudana exposed to 10,50 , and $100 \mu \mathrm{M} \mathrm{Cd}$ for $24 \mathrm{~h}$. distributed in the cell wall and soluble and cell organelle fractions, respectively. The evidence indicated that the cell wall was the main accumulation site for $\mathrm{Cd}$.

\section{Chemical Forms of Cd}

Cd bound to the different chemical forms in the roots of $S$. matsudana can be measured with different extracting agents. The Cd content and the percentage of the variety of chemical forms were shown in Table 3 and Fig. 5. The $\mathrm{Cd}$ content of the different chemical forms $(\mathrm{CdE}, \mathrm{Cdw}$, $\mathrm{CdNaCl}, \mathrm{CdHAc}, \mathrm{CdHCl}$, and $\mathrm{Cdr})$ in roots all increased significantly $(P<0.05)$ with increasing concentrations of $\mathrm{Cd}$ (Table 3). The proportion of the chemical forms varied with $\mathrm{Cd}$ concentration used during the whole experimental treatment (Fig. 5). The proportion of $\mathrm{CdNaCl}$ in roots exposed to 10 and $50 \mu \mathrm{M} \mathrm{Cd}$ was the highest, follow by $\mathrm{CdHCl}, \mathrm{CdHAc}, \mathrm{Cdw}, \mathrm{CdE}$, and $\mathrm{Cdr}$. However, at $100 \mu \mathrm{M} \mathrm{Cd}$, the proportion of $\mathrm{Cd}$ chemical form from high to low is in the order: $\mathrm{CdNaCl}>\mathrm{CdHAc}>\mathrm{CdHCl}>\mathrm{Cdw}$ $>\mathrm{CdE}>\mathrm{Cdr}$, respectively. During the whole experiment, the proportion of $\mathrm{Cd}$ extracted by $0.6 \mathrm{M} \mathrm{HCl}$ and $2 \%$ $\mathrm{HAc}$ increased with increasing $\mathrm{Cd}$ concentrations, while the proportion of $\mathrm{Cd}$ extracted by $1 \mathrm{M} \mathrm{NaCl}$ decreased (Fig. 5).

\section{Discussion}

Recently, fluorescent Cd reagent has been applied only rarely in plant cytological studies. Cd ions have a high affinity for sulphur-, nitrogen-, or oxygen-containing ligands. They can bind strongly to SH-containing enzymes/proteins inside the cell. Obviously, Leadmium Green AM dye has higher affinity for Cd than internal proteins [28] and is not sensitive to other divalent ions

Table 3. Different chemical forms of Cd in roots of S. matsudana exposed to 10, 50, and $100 \mu \mathrm{M} \mathrm{Cd}$ for $24 \mathrm{~h}$.

\begin{tabular}{|c|c|c|c|c|c|c|}
\hline \multirow{2}{*}{$\begin{array}{c}\text { Treatment } \\
(\mu \mathrm{M})\end{array}$} & \multicolumn{6}{|c|}{ Extractable form $(\mu \mathrm{g} / \mathrm{g} \mathrm{FW})$} \\
\cline { 2 - 7 } & $\mathrm{CdE}$ & $\mathrm{CdW}$ & $\mathrm{CdNaCl}$ & $\mathrm{CdHAc}$ & $\mathrm{CdHCl}$ & $\mathrm{CdR}$ \\
\hline 10 & $7.85 \pm 0.15 \mathrm{a}$ & $24.36 \pm 0.80 \mathrm{a}$ & $115.12 \pm 0.70 \mathrm{a}$ & $55.18 \pm 2.29 \mathrm{a}$ & $60.52 \pm 0.21 \mathrm{a}$ & $7.64 \pm 0.06 \mathrm{a}$ \\
\hline 50 & $17.36 \pm 0.19 \mathrm{~b}$ & $45.20 \pm 0.55 \mathrm{~b}$ & $374.92 \pm 1.19 \mathrm{~b}$ & $196.92 \pm 1.124 \mathrm{~b}$ & $208.24 \pm 3.59 \mathrm{~b}$ & $10.06 \pm 0.43 \mathrm{~b}$ \\
\hline 100 & $40.50 \pm 0.97 \mathrm{c}$ & $85.75 \pm 2.11 \mathrm{c}$ & $493.53 \pm 2.29 \mathrm{c}$ & $446.52 \pm 2.62 \mathrm{e}$ & $427.19 \pm 2.67 \mathrm{c}$ & $32.49 \pm 0.31 \mathrm{c}$ \\
\hline
\end{tabular}

Values followed by different letters differ significantly from each other $(P<0.05, t$-test $)$. Means $\pm \mathrm{SE}, \mathrm{n}=4$. 


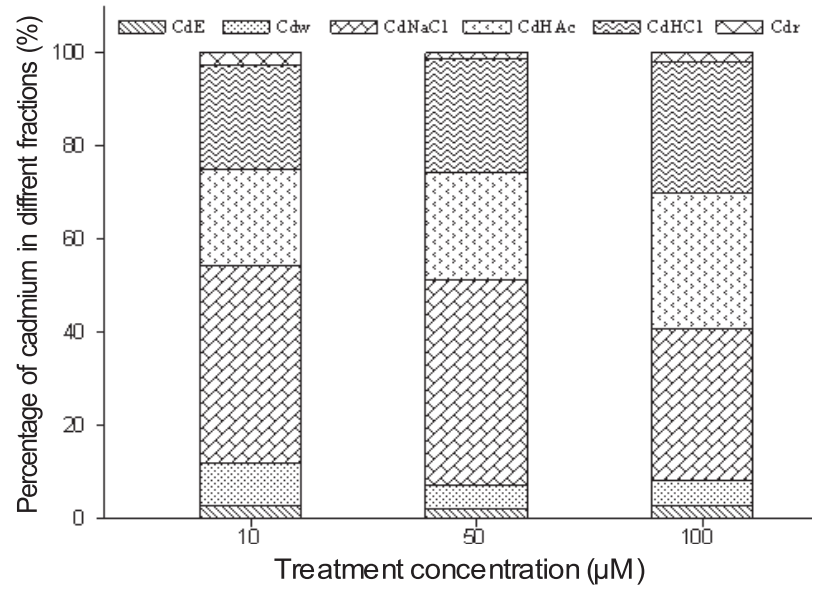

Fig. 5. Different chemical forms of Cd proportion in roots of S. matsudana exposed to 10,50 , and $100 \mu \mathrm{M} \mathrm{Cd}$ for $24 \mathrm{~h}$.

except for lead. In this work, the uptake of $\mathrm{Cd}$ into root cells of $S$. matsudana using Cd-sensitive Leadmium Green was studied, suggesting that the meristematic zone is the primary site of Cd uptake and accumulation, which supported our previous observations, where Cd was found to be absorbed within hours in the root cells of Allium sativum exposed to $\mathrm{Cd}$ [29]. As for excessive $\mathrm{Cd}$ ions accumulating in the meristem (50 and $100 \mu \mathrm{M} \mathrm{Cd}$ ), they disturb cell division and result in the inhibition of the root growth of $S$. matsudana.

The subcellular distribution of $\mathrm{Cd}$ in plants is thought to be important in influencing the accumulation, migration, and phytotoxicity of $\mathrm{Cd}$ in different species or genotypes $[16,30]$. Plant cell walls contain polyoses such as cellulose, hemicellulose, lignin, and mucilage glue as well as proteins, and can potentially bind to $\mathrm{Cd}$ ions and restrict $\mathrm{Cd}$ from entering the cell protoplast and moving to the upper parts of the plant [16]. In the present investigation about $53 \%$ of the Cd was accumulated in the cell wall of $S$. matsudana roots at $10 \mu \mathrm{M} \mathrm{Cd}$ and $65 \%$ of the $\mathrm{Cd}$ at $100 \mu \mathrm{M} \mathrm{Cd}$, indicating that $\mathrm{Cd}$ binding and/or precipitation in the cell wall in roots may serve as the first barrier to reduce the cytosolic free $\mathrm{Cd}$ ions and lessen the damage to the root cells (Table 2).

The results obtained here are consistent with earlier findings [7, 11, 31, 32]. However, Carrier et al. [33] reported that approximately $80 \%$ of $\mathrm{Cd}$ was found predominantly in the soluble fraction, and relatively little Cd was found in the cell wall (11\%). Lozano-Rodríguez et al. [34] indicated that maize was more tolerant to $\mathrm{Cd}$ than pea by incorporating more $\mathrm{Cd}$ into the cell wall, while pea showed more severe damage caused by higher concentration of $\mathrm{Cd}$ in the soluble fraction. Thus plant responses to $\mathrm{Cd}$ may be affected by the species, cultivar, and stress level $[35,36]$. The retention of $\mathrm{Cd}$ in root cell walls and compartmentalization of Cd into vacuoles are the most important mechanisms involved in the detoxification of Cd in S. matsudana.

The next large proportion of Cd in S. matsudana roots was observed in soluble fractions in this work (Fig. 4).
Once $\mathrm{Cd}$ ions are inside the cytosol, plants can avoid $\mathrm{Cd}$ stress by minimizing the concentration of free $\mathrm{Cd}$ in the cytosol by forming metal chelates/complexes [37-38]. The high proportion of $\mathrm{Cd}$ in the soluble fraction may limit root-to-shoot translocation of $\mathrm{Cd}$, resulting in low $\mathrm{Cd}$ levels in the shoots [39].

It has been reported that $\mathrm{Cd}$ chemical forms in plants are considered important factors that affect the characteristics of $\mathrm{Cd}$ migration, accumulation, and phytotoxicity degree $[13,30]$. Water-soluble $\mathrm{Cd}$ in inorganic form (extracted by $80 \%$ ethanol) and organic form (extracted by $\mathrm{H}_{2} \mathrm{O}$ ) are thought to have more deleterious and induced stunted growth and chlorosis in the plants due to its highest capacity to migrate, followed by pectate-and proteinintegrated $\mathrm{Cd}(\mathrm{NaCl}$ fraction), undissolved $\mathrm{Cd}$ phosphates (HAC fraction), oxalic-acid bound form ( $\mathrm{HCl}$ fraction), and residues [13, 30, 32, 40].

The high $\mathrm{Cd}$ concentrations of the toxic forms of $\mathrm{Cd}$ in the cell organelles could seriously damage the cells and the metabolic processes in plants [7]. In the present investigation we observed that the proportion of $\mathrm{CdE}$ and $\mathrm{Cdw}$ in roots is low when compared with the other $\mathrm{Cd}$ chemical forms. $\mathrm{CdHCl}, \mathrm{Cdr}$, and $\mathrm{CdHAc}$ represent $46 \%$ (10 $\mu \mathrm{M} \mathrm{Cd}), 49 \%$ (50 $\mu \mathrm{M} \mathrm{Cd}$ ), and 59\% (100 $\mu \mathrm{M} \mathrm{Cd})$ of total $\mathrm{Cd}$, indicating that the $\mathrm{Cd}$ is transformed into a nontoxic or low toxicity complex to protect the cells. $\mathrm{CdNaCl}$ represents $42 \%$ (10 $\mu \mathrm{M} \mathrm{Cd}), 44 \%(50 \mu \mathrm{M} \mathrm{Cd})$, and 32\% (100 $\mu \mathrm{M} \mathrm{Cd})$. It was demonstrated that $\mathrm{NaCl}$ extractant binds to proteins and pectic acids, with $\mathrm{Cd}$ being fixed by pectic acids [7]. Vacuolar sequestration and cell wall binding play a major role in hyperaccumulation of heavy metals [8]. The vacuole appears to be the main site for Cd accumulation in the plant. Salt et al. [41] indicated that the organo-ligands responsible for $\mathrm{Cd}$ compartmentation in the vacuoles were mainly sulfur-rich peptides and organic acids. Wu et al. [26] reported that a Cd-sensitive barley genotype had a larger amount of $\mathrm{Cd}$ in inorganic and water-soluble forms as compared with the Cd-resistant genotypes. The cell wall is the first barrier protecting the protoplast from $\mathrm{Cd}$ toxicity because it is composed of polyoses and protein [42]. As Cd has a strong affinity to proteins or sulfhydryl compounds $(-\mathrm{SH})$ and other side chains, it can easily combine with proteins [5] and disturb enzyme activity [7]. It was reported that the cell wall played a role in metal tolerance when the cell wall volume was high compared to the cytosol and vacuole [43].

The data from inductively coupled plasma mass spectrometry (ICP-MS) revealed that $56 \%$ of total $\mathrm{Cd}$ was located in cell walls of Allium cepa epidermal cells exposed to Cd [31]. Similarly, the data from energydispersive $\mathrm{x}$-ray analyses (EDXA) indicated that $\mathrm{Cd}$ ions appeared in walls of root cells of $A$. cepa treated with $\mathrm{Cd}$ [42]. Cytochemical evidence also confirmed that cysteinerich proteins were localized in electron-dense granules in root cell walls of $A$. cepa [44], which seemed to contribute substantially to $\mathrm{Cd}$ detoxification.

$\mathrm{Cd}$ can alter the uptake of minerals by plants through its effects on the availability of minerals from the soil, or through a reduction in the population of soil microbes 
[45]. Microelements such as $\mathrm{Zn}, \mathrm{Fe}, \mathrm{Ca}$, and $\mathrm{Mn}$ play a vital role in mitigating $\mathrm{Cd}$ stress to plants by activating certain $\mathrm{Cd}$ avoidance and/or tolerance mechanisms in plants $[23,46] . \mathrm{Mn}$ is an essential micronutrient in plants and is associated with some Mn-metalloproteins [47]. The availability of $\mathrm{Mn}$ to plants decreases in the presence of $\mathrm{Cd}$ in soil [48].

Data from this investigation showed that $\mathrm{Mn}$ accumulation was reduced significantly $(P<0.05)$ in $S$. matsudana roots exposed to different $\mathrm{Cd}$ concentrations, and progressively decreased with an increase in $\mathrm{Cd}$ concentration. Dong et al. [49], through regression analysis, showed that there was a significantly negative correlation between $\mathrm{Cd}$ and $\mathrm{Mn}$, implying an antagonistic effect of $\mathrm{Cd}$ on $\mathrm{Mn}$ absorption and translocation. Peng et al. [50] found that adding $\mathrm{Mn}$ to the solution containing $\mathrm{Cd}$ significantly improved plant growth and reduced the concentrations of $\mathrm{Cd}$ in all organs of the plant. $\mathrm{Zn}$ is known to play a crucial role in protein metabolism, gene expression, chromatin structure, and photosynthetic carbon metabolism [51]. In addition, it is associated with the stabilizing and protective effect on biomembranes against oxidative and peroxidative damage, loss of plasma membrane integrity, and alteration of the permeability of the membrane [52, 53]. The results here revealed that $\mathrm{Zn}$ accumulation in roots decreased significantly $(P<0.05)$ with increasing $\mathrm{Cd}$ concentration. There is a strong competition between $\mathrm{Zn}$ and $\mathrm{Cd}$ [54], because $\mathrm{Cd}$ and $\mathrm{Zn}$ are taken up as divalent cations and have a similar chemistry $[1,55]$. The Fe level in roots of $S$. matsudana showed significant decrease under Cd stress. Kovács et al. [56] indicated that $\mathrm{Fe}$ ions may compete with $\mathrm{Cd}$ ions for the same membrane binding (transport) sites in plants, and so an adequate $\mathrm{Fe}$ ion supply may decrease Cd uptake and relieve $\mathrm{Cd}$ toxicity in plants. Studies have provided clear evidence that $\mathrm{Fe}$ can alleviate to some extent the Cd-induced inhibitory effects on plant growth [1]. For instance, adding an Fe supply to plants exposed to $\mathrm{Cd}$ can result in increased activity of antioxidative enzymes - an important defensive mechanism against oxidative stress [57]. Data from ICP-AES in the present investigation showed that $\mathrm{Ca}$ content in the roots of $S$. matsudana exposed to $\mathrm{Cd}$ decreases significantly $(P<0.05)$. It is well known that $\mathrm{Cd}$ and $\mathrm{Ca}$ have similar ionic radii $(0.099 \mathrm{~nm}$ and $0.097 \mathrm{~nm}$, respectively). Shortly after $\mathrm{Cd}$ enters the cytoplasm, it rapidly binds to certain sites of the root tip apoplast, modifying the concentration of free cytosolic $\mathrm{Ca}$ ions, affecting the function of the plasmalemma pumps transporting $\mathrm{Ca}^{2+}$, and resulting in a disturbance of $\mathrm{Ca}$ uptake and physiological activities.

\section{Conclusions}

Based on the information provided in this article, it is concluded that:

1. Under $\mathrm{Cd}$ stress, more $\mathrm{Cd}$ ions exist in the meristem zone, suggesting that the meristem zone of root tips is the main site of $\mathrm{Cd}$ uptake and accumulation.
2. Contents of $\mathrm{Mn}, \mathrm{Zn}, \mathrm{Fe}$, and $\mathrm{Ca}$ in the root tip cells of S. matsudana decrease, while $\mathrm{Cd}$ level increases.

3. Cd ions mainly exist in cell walls, suggesting that the cell wall barrier is crucial for the detoxification of $\mathrm{Cd}$.

4. The proportion of $\mathrm{CdE}$ and $\mathrm{Cdw}$ in roots is very low, although they have more deleterious biological activity. $\mathrm{CdHCl}, \mathrm{Cdr}$, and $\mathrm{CdHAc}$ have low toxic effects when compared with $\mathrm{CdNaCl}$. $\mathrm{CdNaCl}$ represent $42 \%$ (10 $\mu \mathrm{M} \mathrm{Cd}), 44 \%$ (50 $\mu \mathrm{M} \mathrm{Cd})$, and 32\% (100 $\mu \mathrm{M} \mathrm{Cd})$ of total $\mathrm{Cd}$. It can be suggested that $\mathrm{Cd}$ integrated with pectates and proteins in cell walls may be responsible for the adaptation of S. matsudana to Cd stress.

\section{Acknowledgements}

This project was supported by the National Natural Science Foundation of China (grant No. 30972331). The authors wish to express their appreciation to the reviewers for their comments and suggestions.

\section{References}

1. CHOPPALA G., SAIFULLAH BOLAN N., BIBI S., IQBAL M., RENGEL Z., KUNHIKRISHNAN A., ASHWATH N., SIK OY. Cellular mechanisms in higher plants governing tolerance to cadmium toxicity. Crit. Rev. Plant. Sci. 33, 374, 2014.

2. DALCORSO G., FARINATI S., MAISTRI S., FURINI A. How plants cope with cadmium: staking all on metabolism and gene expression. J. Integr. Plant Biol. 50, 1268, 2008.

3. REDJALA T., STERCKEMAN T., MOREL J.L. Cadmium uptake by roots: contribu-tion of apoplast and of high- and low-affinity membrane transport systems. Environ. Exp. Bot. 67, 235, 2009.

4. LIN Y.F., AARTS G.M. The molecular mechanism of zinc and cadmium stress response in plants. Cell Mol. Life Sci. 69, 3187, 2012.

5. SANITÀ DI TOPPI L., GABBRIELLI R. Response to cadmium in higher plants. Environ. Exp. Bot. 41, 105, 1999.

6. GE W., JIAO Y.Q., SUN B.L., QIN R., JIANG W.S., LIU D.H. Cadmium-mediated oxidative stress and ultrastructural changes in root cells of poplar cultivars. S. Afr. J. Bot. 83, 98, 2012.

7. WENG B.S., XIE X.Y., WEISS D.J., LIU J.C., LU H.L., YAN C.L. Kandelia obovata (S., L.) Yong tolerance mechanisms to cadmium: sub-cellular distribution, chemical forms and thiol pools. Mar. Pollut. Bull. 64, 2453, 2012.

8. ZHANG C.L., ZHANG P., MO C.R., YANG W.W., LI Q.F., PAN L.P., LEE D.K. Cadmium uptake, chemical forms, subcellular distribution, and accumulation in Echinodorus osiris Rataj. Environ. Sci. Proc. Imp. 15, 1459, 2013.

9. CLEMENS S. Molecular mechanisms of plant metal tolerance and homeostasis. Planta 212, 475, 2001.

10. HALL J.L. Cellular mechanisms for heavy metal detoxification and tolerance. J. Exp. Bot. 53, 1, 2002.

11. ZHANG W., LIN K.F., ZHOU J., ZHANG W., LIU L.L., ZHANG Q.Q. Cadmium accumulation, subcellular distribution and chemical forms in rice seedling in the presence of sulfur. Environ. Toxicol. Phar. 37, 348, 2014.

12. FU X.P., DOU C.M., CHEN Y.X., CHEN X.C., SHI J.Y., YU M.G., XU J. Subcellular distribution and chemical forms 
of cadmium in Phytolacca americana L. J. Hazard. Mater. 186, 103, 2011.

13. XU P.X., WANG Z.L. Physiological mechanism of hypertolerance of cadmium in Kentucky bluegrass and tall fescue: Chemical forms and tissue distribution. Environ. Exp. Bot. 96, 35, 2013.

14. ERNST W.H.O., VERKLEIJ J.A.C., SCHAT H. Metal tolerance in plants. Acta. Bot. Neerl. 41, 229, 1992.

15. RAUSER W.E. Structure and function of metal chelators produced by plants: the case for organic acids, amino acids, phytin, and metallothioneins. Cell Biochem. Biophys. 31, 19, 1999.

16. QIU Q., WANG Y.T., YANG Z.Y., YUAN J.G. Effects of phosphorus supplied insoil on subcellular distribution and chemical forms of cadmium in two Chinese flowering cabbage (Brassica parachinensis L.) cultivars differing in cadmiumaccumulation. Food Chem. Toxicol. 49, 2260, 2011.

17. YU H., XIANG Z.X., ZHU Y., WANG J.L., YANG Z.J., YANG Z.Y. Subcellular andmolecular distribution of cadmium in two rice genotypes with different levels of cadmium accumulation. J. Plant Nutr. 35, 71, 2012.

18. ZHAO Y.F., WU J.F., SHANG D., NING J.S., ZHAI Y.X., SHENG X.F., DING H.Y. Subcellular distribution and chemical forms of cadmium in the edible seaweed, Porphyra yezoensis. Food Chem. 168, 48, 2015.

19. DIMITRIOU I., ARONSSON P. Landfill leachate treatment with willows and poplars-efficiency and plant response. Waste Manag. 30, 2137, 2010.

20. YANG J.L., CHEN Z., WU S.Q., CUI Y., ZHANG L., DONG H., YANG C.P., LI C.H. Overexpression of the Tamarix hispida ThMT3 gene increases copper tolerance and adventitious root induction in Salix matsudana Koidz. Plant Cell Tiss. Org. 121, 1, 2015.

21. DICKINSON N.M., PULFORD I.D. Cadmium phytoextraction using short-rotation coppice Salix: the evidence trail. Environ. Int. 31, 609, 2005.

22. DOS SANTOS UTMAZIAN M.N., WIESHAMME G., VEGA R., WENZEL W.W. Hydroponic screening for metal resistance and accumulation of cadmium and zinc in twenty clones of willows and poplars. Environ. Pollut. 148, 155, 2007.

23. SARWAR N., SAIFULLAH M.S.S., ZIA M.H., NAEEM A., BIBI S., FARID G. Role of mineral nutrition in minimizing cadmium accumulation by plants. J. Sci. Food Agric. 90, 925, 2010.

24. GU J.G., QI L.W., JIANG W.S., LIU D.H. Cadmium accumulation and its effects on growth and gas exchange in four Populus cultivars. Acta. Biol. Cracov. Bot. 49, 7, 2007.

25. WEIGEL H.J., JAGER H.J. Subcellular distribution and chemical form of cadmium in bean plants. Plant Physiol. 65, 480, 1980.

26. WU F.B., DONG J., QIAN Q.Q., ZHANG G.P. Subcellular distribution and chemical form of $\mathrm{Cd}$ and $\mathrm{Cd}-\mathrm{Zn}$ interaction in different barley genotypes. Chemosphere 60, 1437, 2005.

27. ZHAO F.Y., HU F., ZHANG S.Y., WANG K., ZHANG C.R., LIU T. MAPKs regulate root growth by influencing auxin signaling and cell cycle-related gene expression in cadmiumstressed rice. Environ. Sci. Pollut. Res. 20, 5449, 2013.

28. JAVED M.T., LINDBERG S., GREGER M. Cadmium uptake in Elodea canadensis leaves and its interference with extra- and intra-cellular pH. Plant Biol. 16, 615, 2014.

29. [JIANG W.S., LIU D.H., XU P. Cd-induced system of defence in the garlic root meristematic cells. Biol. Plantarum 53, 369, 2009.

30. WANG X., LIU Y.G., ZENG G.M., CHAI L.Y., SONG X.C., MIN Z.Y., XIAO X. Subcellular distribution and chemical forms of cadmium in Bechmeria nivea (L.) Gaud. Environ. Exp. Bot. 62, 389, 2008.

31. WIERZBICKA M.H., PRZEDPEŁSKA E., RUZIK R., OUERDANE L., POŁEĆ-PAWLAK K., JAROSZ M., SZPUNAR J., SZAKIEL A. Comparison of the toxicity and distribution of cadmium and lead in plant cells. Protoplasma 231, 99, 2007.

32. XUE M., ZHOU Y.H., YANG Z.Y., LIN B.Y., YUAN J.G., WU S.S. Comparisons in subcellular and biochemical behaviors of cadmium between low-Cd and high-Cd accumulation cultivars of pakchoi (Brassica chinensis L.). Front. Environ. Sci. Eng. 8, 226, 2014.

33. CARRIER P., BARYLA A., HAVAUX M. Cadmium distribution and microlocalization in oilseed rape (Brassica napus) after long-term growth on cadmium-contaminated soil. Planta 216, 939, 2003.

34. LOZANORODRIGUEZ E., HERNANDEZ L.E., BONAY P., CARPENARUIZ R.O. Distribution of cadmium in shoot and root tissues of maize and pea plants: physiological disturbances. J. Exp. Bot. 48, 123, 1997.

35. MIAO A.J., WANG W.X. Cadmium toxicity to two marine phytoplankton under different nutrient conditions. Aquat. Toxicol. 78, 114, 2006.

36. LIU J.G., QU P., ZHANG W., DONG Y., LI L., WANG M.X. Variations among rice cultivars in subcellular distribution of $\mathrm{Cd}$ : The relationship between translocation and grain accumulation. Environ. Exp. Bot. 107, 25, 2014.

37. VERKLEIJ J.A.C., GOLAN-GOLDHIRSH A., ANTOSIEWISZ D.M., SCHWITZGUEBEL J.P., SCHRODER P. Dualities in plant tolerance to pollutants and their uptake and translocation to the upper plant parts. Environ. Exp. Bot. 67, 10, 2009.

38. SARASWAT S., RAI J.P.N. Complexation and detoxification of $\mathrm{Zn}$ and $\mathrm{Cd}$ in metal accumulating plants. Rev. Environ. Sci. Biotechnol. 10, 327, 2011.

39. SU Y., LIU J., LU Z., WANG X., ZHANG Z., SHI G. Effects of iron deficiency on subcellular distribution and chemical forms of cadmium in peanut roots in relation to its translocation. Environ. Exp. Bot. 97, 40, 2014.

40. ZHANG S.J., HU F., LI H.X. Effects of earthworm mucus and amino acidson cadmium sub-cellular distribution and chemical forms in tomato seedlings. Bioresource Technol. 100, 4041, 2009.

41. SALT D.E., SMITH R.D., RASKIN I. Phytoremediation. Annu Rev Plant Physiol. Plant Mol. Biol. 49, 643, 1998.

42. LIU D.H., KOTTKE I., ADAM D. Localization of cadmium in the root cells of Allium cepa by energy dispersive X-ray analysis. Biol. Plant 51, 363, 2007.

43. NEUMANN D., ZUR NIEDEN U., SCHWIEGER W., LEOPOLD I., LICHTENBERGER O. Heavy metal tolerance of Minuartia erna. J. Plant Physiol. 151, 101, 1997.

44. LIU D.H., KOTTKE I. Subcellular localization of cadmium in the root cells of Allium cepa by electron energy loss spectroscopy and cytochemistry. J. Biosci. 29, 329, 2004.

45. BENAVIDES M.P., GALLEGO S.M., TOMARO M.L. Cadmium toxicity in plants. Braz. J. Plant Physiol. 17, 21, 2005.

46. SAIFULLAH S.N., BIBI S., AHMAD M., OK Y.S. Effectiveness of zinc application to minimize cadmium toxicity and accumulation in wheat (Triticum aestivum L.). Environ. Earth Sci. 71, 1663, 2014.

47. MARSCHNER H. Mineral nutrition of higher plants. Academic Press, NY. 1995.

48. Nazar R., Iqbal N., Masood A., Khan M.R., Syeed S., Khan N.A. Cadmium toxicity in plants and role of mineral nutrients in its alleviation. Amer. J. Plant Sci. 3, 1476, 2012. 
49. DONG J., WU F., ZHANG G. Influence of cadmium on antioxidant capacity and four microelement concentrations in tomato seedlings (Lycopersicon esculentum). Chemosphere 64, 1659, 2006.

50. PENG K.J., LUO C.L., YOU W.X., LIAN C.L., LI X.D., SHEN Z.G. Manganese uptake and interactions with cadmium in the hyperaccumulator-Phytolacca Americana $L$. J. Hazard. Mater. 154, 674, 2008.

51. BALEN B., TKALEC M., SIKIĆ S., TOLIĆ S., CVJETKO P., PAVLICA M., VIDAKOVIĆ-CIFREK Z. Biochemical responses of Lemna minor experimentally exposed to cadmium and zinc. Ecotoxicol. 20, 815, 2011.

52. ZHAO Z.Q., ZHU Y.G., KNEER R., SMITH R.E. Effect of zinc on cadmium toxicity-induced oxidative stress in winter wheat seedlings. J. Plant Nutr. 28, 1947, 2005.

53. HANSCH R., MENDEL R.R. Physiological functions of mineral micronutrients $(\mathrm{Cu}, \mathrm{Zn}, \mathrm{Mn}, \mathrm{Fe}, \mathrm{Ni}, \mathrm{Mo}, \mathrm{B}, \mathrm{Cl})$.
Curr. Opin. Plant Biol. 12, 259, 2009

54. HART J.J., WELCH R.M., NORVELL W.A., KOCHIAN L.V. Transport interactions between cadmium and zinc in roots of bread and durum wheat seedlings. Physiol. Plantarum 116, 73, 2002.

55. NIEBOER E., RICHARDSON D.H.S. The replacement of the nondescript term 'heavymetals' by a biologically and chemically significant classification of metal ions. Environ. Pollut. 1, 3, 1980.

56. KOVÁCS K., KUZMANN E., VERTES A., LEVAI L., CSEH E., FODOR F. Effect of cadmium on iron uptake in cucumber roots: a Mossbauer-spectroscopic study. Plant Soil 327, 49, 2010.

57. GRATÃO P.L., POLLE A., LEA P.J., AZEVEDO R.A. Making the life of heavy metal stressed plants a little easier. Funct. Plant Biol. 32, 32481, 2005. 